\title{
NASA FUNDING IN CONGRESS: MONEY MATTERS
}

\author{
Martin Machay ${ }^{1}$, Alan Steinberg ${ }^{2}$ \\ ${ }^{1}$ Mendel University in Brno, Czech Republic \\ ${ }^{2}$ West Houston Association, United States of America
}

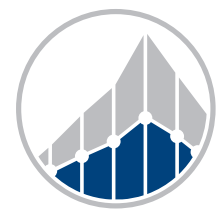

EUROPEAN JOURNAL OF BUSINESS SCIENCE AND TECHNOLOGY

Volume 6 Issue 1

ISSN 2694-7161

www.ejobsat.com

\begin{abstract}
This paper argues that individual members of Congress engage in economic opportunism, voting in the best interests of their constituents based on economic heuristics, when considering space policy legislation. Multivariable logit analysis is conducted on five votes in the House of Representatives to test the hypotheses. The economic opportunism effect is captured in the models by the presence of NASA Centers, relative importance of space industry and NASA procurements. Findings suggest that economic benefits to a member's constituency can play an important role in legislative voting, particularly when legislation deals with federal aerospace funding, when space policy bills lack over-reaching bi-partisan support. In recent years the National Aeronautics and Space Administration (NASA) has seen its funding fall prey to partisan budget battles and party line voting, but this was not historically the norm. As we move forward into a future where NASA funding may become more scrutinized and politicized, this paper supports the thesis that individual members of Congress care more about the funds for their constituents than the other aspects of space policy.
\end{abstract}

\section{KEY WORDS}

space policy, economic opportunism, legislative behavior, NASA, budgeting

\section{JEL CODES}

H11, H57, K39, Z18

\section{INTRODUCTION}

In the months before the U.S. Government shutdown of 2013, the U.S. Senate and the U.S. House of Representatives faced a showdown over the reauthorization of the National Aero- nautics and Space Administration (NASA)'s budget for 2014-2016. For the most part, NASA reauthorizations have been non-partisan endeavors, and even when they are somewhat 
partisan, the lines are not drawn as close as was seen in the confrontation between H.R.2687 and S.1317, the House and Senate versions of the National Aeronautics and Space Administration Authorization Act of 2013. H.R.2687 authorized about $\$ 1.5$ billion less per year from 2014 through 2016 than S.1317, a roughly $8 \%$ budget cut by comparison. Each bill was only narrowly approved by its respective committee along party lines (Committee on Science, Space and Technology, 2013; King, 2013; SpaceRef, 2013 and Leone, 2013). Subsequently, neither bill was voted on or even called to the floor in its respective chamber. This confrontation marked the first time NASA authorization legislation fell prey to strict partisan voting, but not the first time that NASA authorization was subject to politicization.

This seemingly rare event leads us to wonder what is in store regarding the future of NASA funding, and to question what motivated legislators to support or oppose space related legislation in the past. The case for supporting NASA funding is often made out of national interest, but legislators may actually be more opportunistic in their voting behavior. Congress members could be supporting space legislation based upon the relative importance of space activities within their state, in essence voting to improve the economic situations within their states through federal dollars directed to NASA (Machay and Steinberg, 2015). This follows in line with the theory that members of Congress are likely to work in the interests of particular industries when legislation directly impacts an industry with an important role within their district (Kingdon, 1989).

This paper demonstrates that members of Congress are opportunistic in regards to their support towards space legislation; supporting or opposing space legislation that benefits their constituency rather than the nation as a whole. Specifically, we argue that the impact of the space industry within their state is a major factor towards the likelihood that a member of Congress supports legislation that relates to NASA funding due to potential direct benefits the funding will have for their constituents. This paper also tries to end the period of underutilization of U.S. Congress votes data (Pomeroy, 2019).

This study starts by discussing the history of space legislation in Congress and identifies roll call votes of interest that allow for the testing of potential motivations for voting decisions in regards to space policy and its funding. Then, considering established theories of legislative behavior pertaining to voting, we develop two specific testable hypotheses regarding the motivations of member of Congress choosing to support or oppose space legislation. Multivariable logit analysis is conducted to test the hypotheses and results are presented. The study concludes with implications of the findings regarding the future of legislative behavior towards space policy, and avenues for continued research.

\section{LEGISLATIVE BEHAVIOR TOWARDS SPACE POLICY}

Legislative behavior is a complication of a member of Congress wishing to enact good public policy while looking to satisfy constituents and balance the influences of their party, other legislators, and the administration (Kingdon, 1977). Their voting is thus based on self-interest theory where the legislator is likely to vote for bills in the economic or ideological interest of their constituency, or engage in other actions, such as logrolling or pandering to special interests, all in line to benefit their potential re-election (see for example Mayhew, 1974; Fiorina, 1974; Stigler, 1971; Kau and Rubin, 1979; Peltzman, 1984 and Kingdon, 1989).

Members of Congress consider policy along a dimension, voting for or against a policy based on the proximity to where they stand on the issue both personally and in regards to 
their constituent's interests, while also relying on cues from other members and their party more generally (MacRae, 1958; Clausen, 1973; Stimson, 1975; Snyder and Groseclose, 2000; Ansolabehere et al., 2001 and Kingdon, 1989). In regards to budgetary legislation, changes are made slowly with only small increases or decreases based on previous decisions and actions (Wildavsky, 1964 and Davis et al., 1966).

In regards to constituent desires towards space policy, there does not appear to be a clear relationship whereby members would vote for legislation leading to increased federal space spending based on public opinion (Steinberg, 2011). Moreover, as the majority of the population lacks solid awareness of NASA's budget in the first place, public opinion on the issue is likely to play only a small roll in congressional decision making (Launius, 2003 and Steinberg, 2013). Additionally, compared to the number of bills considered by Congress, space legislation is relatively rare. This implies that few members of Congress are likely to be highly knowledgeable in this issue area and must instead rely on party cues or economic heuristics.

The structure of the institutions within Congress suggests space policy is important as both houses maintain specific subcommittees to address space policy related issues. In the Senate there is a Subcommittee on Space, Science, and Competitiveness having responsibility for space science and policy, currently chaired by Texas Senator Ted Cruz. The Subcommittee on Space of the House of Representatives is currently chaired by republican Texas Representative Brian Babin. Perhaps not surprisingly, the membership of both subcommittees consists of a disproportionate number of legislators from states with strong aerospace ties. Despite this strong institutional structure, many pieces of space related legislation fail to make it to the floor for a vote because the bills involve dramatic changes in space policy. ${ }^{1}$ The lives of these drafts are short and usually their only action is they are referred to the given subcommittee.

Historically, ideology manifested through the political party system has appeared to play a role in space policy, but the degree to which this happens is far from clear. Previous research is full of antidotes suggesting that legislators of different parties had clearly distinctive preferences towards space policy. During the 1970s for example, there were partisan debates regarding manned versus unmanned programs and both programs vis-a-vis domestic social programs. Examples of such conflicts still show members breaking party ranks when economic interests come into play (Hoff, 1997). Additionally, party line voting may be more an artifact of supporting the president rather than related to a partisan issue agenda. For example, a dozen Republican legislators who voted to support the International Space Station while George H. W. Bush was president switched their votes when the legislation re-appeared under the Clinton administration; similarly thirteen Democrats in the house also switched from "nay" to "yea" (Launius and McCurdy, 1997). These examples suggest party cues may not be as important as economic ones.

Over the last twenty-five years, bills regarding NASA appropriation have, for the most part, avoided major controversy by calling for only minor changes in space policy. In the last quarter century there have been 25 bills which were voted on by Congress as a whole and then presented to the President. They are listed in Tab. 1. In the Senate none of these bills have recorded votes, and only eight of these bills have recorded votes in the House of Representatives plus one that failed in the Senate. This makes 10 recorded votes in total. Of these votes, five votes passed the bill with near unanimous support. This leaves us with five votes by which we can test for the potential of opportunistic voting by members of Congress, which will be addressed in detail below.

\footnotetext{
${ }^{1}$ Supportive bills included for example H.R.3057 Space Exploration Act of 2003, H.R.3898 Zero Gravity, Zero Tax Act of 2000 or H.R.1631 National Space Port Act of 1995. Restrictive bills included H.R.407 To terminate the International Space Station Alpha program of 1995 or H.R.2656 To cancel the participation of the United States in the Space Station program of 1995.
} 
Tab. 1: Space Legislation in Congress - Presented to President

\begin{tabular}{|c|c|c|c|c|}
\hline Bill Nr. & Introduced & Title (abbreviated if necessary) & House & Senate \\
\hline S.1180 & $6 / 14 / 1989$ & $\begin{array}{l}\text { A bill to authorize the President to appoint Richard } \\
\text { Harrison Truly to the Office of Administrator of NASA }\end{array}$ & Passed & Passed \\
\hline S. 2124 & $2 / 8 / 1990$ & National Space Council Authorization Act of 1990 & Passed & Passed \\
\hline S. 2287 & $3 / 9 / 1990$ & NASA Authorization Act, Fiscal Year 1991 & Passed & Passed \\
\hline H.J.Res.214 & $4 / 11 / 1991$ & $\begin{array}{l}\text { To recognize the Astronauts Memorial at the J. F. K. } \\
\text { Space Center as the national memorial to astronauts } \\
\text { who die in the line of duty }\end{array}$ & Passed & Passed \\
\hline H.R.1988 & $4 / 23 / 1991$ & NASA Authorization Act, Fiscal Year 1992 & $\begin{array}{l}\text { Passed } \\
361-36\end{array}$ & Passed \\
\hline H.R. 2130 & $4 / 30 / 1991$ & $\begin{array}{l}\text { National Oceanic and Atmospheric Administration } \\
\text { Authorization Act of } 1992\end{array}$ & Passed & Passed \\
\hline S.Con.Res.123 & $5 / 21 / 1992$ & $\begin{array}{l}\text { A resolution authorizing the use of the East Front } \\
\text { parking lot of the Capitol for an exhibit by NASA } \\
\text { during the period } 6 / 1 / 1992 \text { to } 6 / 5 / 1992\end{array}$ & Passed & Passed \\
\hline H.R. 6133 & $10 / 5 / 1992$ & Land Remote Sensing Policy Act of 1992 & Passed & Passed \\
\hline H.R. 6135 & $10 / 5 / 1992$ & NASA Authorization Act, Fiscal Year 1993 & Passed & Passed \\
\hline S.J.Res.187 & $5 / 11 / 1994$ & $\begin{array}{l}\text { A joint resolution designating July } 16 \text { through July } 24,1994, \\
\text { as "National Apollo Anniversary Observance" }\end{array}$ & Passed & Passed \\
\hline H.R.1702 & $5 / 22 / 1997$ & Commercial Space Act of 1998 & Passed & Passed \\
\hline H.R. 1654 & $5 / 3 / 1999$ & NASA Authorization Act of 2000 & $\begin{array}{c}\text { Passed } \\
259-168\end{array}$ & Passed* \\
\hline H.R.1654 & $9 / 14 / 2000$ & NASA Authorization Act of 2000 (*with Conference report) & $\begin{array}{l}\text { Passed } \\
399-17\end{array}$ & Passed \\
\hline H.R.2607 & $7 / 26 / 1999$ & Commercial Space Transportation Competitiveness Act of 2000 & Passed & Passed \\
\hline S.610 & $3 / 13 / 2003$ & NASA Flexibility Act of 2004 & Passed & Passed \\
\hline H.R.5382 & $11 / 18 / 2004$ & Commercial Space Launch Amendments Act of 2004 & $\begin{array}{c}\text { Passed } \\
269-120\end{array}$ & Passed \\
\hline S.1281 & $6 / 21 / 2005$ & NASA Authorization Act of 2005 & Passed & Passed \\
\hline H.Con.Res.448 & $7 / 13 / 2006$ & $\begin{array}{l}\text { Commending the NASA on the completion of the Space } \\
\text { Shuttle's second Return-to-Flight mission }\end{array}$ & Passed & Passed \\
\hline H.R.6063 & $5 / 15 / 2008$ & NASA Authorization Act of 2008 & $\begin{array}{l}\text { Passed } \\
409-15\end{array}$ & Passed \\
\hline H.R.3237 & $7 / 16 / 2009$ & $\begin{array}{l}\text { To enact certain laws relating to national and commercial } \\
\text { space programs as title } 51 \text {, U.S. Code, "National and } \\
\text { Commercial Space Programs" }\end{array}$ & Passed & Passed \\
\hline H.Con.Res.292 & $6 / 30 / 2010$ & $\begin{array}{l}\text { Supporting the goals and ideals of National Aerospace Week, } \\
\text { and for other purposes }\end{array}$ & $\begin{array}{c}\text { Passed } \\
413-0\end{array}$ & Passed \\
\hline S.3729 & $8 / 5 / 2010$ & NASA Authorization Act of 2010 & $\begin{array}{c}\text { Passed } \\
304-118\end{array}$ & Passed \\
\hline H.R.4158 & $3 / 7 / 2012$ & $\begin{array}{l}\text { To confirm full ownership rights for certain U.S. astronauts } \\
\text { to artifacts from the astronauts' space missions }\end{array}$ & Passed & Passed \\
\hline H.R.6586 & $11 / 9 / 2012$ & Space Exploration Sustainability Act & Passed & Passed \\
\hline H.R.667 & $2 / 13 / 2013$ & $\begin{array}{l}\text { To redesignate the Dryden Flight Research Center as the } \\
\text { N. A. Armstrong Flight Research Center and the Western } \\
\text { Aeronautical Test Range as the H. L. Dryden Aeronautical } \\
\text { Test Range }\end{array}$ & $\begin{array}{l}\text { Passed } \\
394-0\end{array}$ & Passed \\
\hline H.R. $4412^{*}$ & $4 / 7 / 2014$ & NASA Authorization Act of 2014 & $\begin{array}{c}\text { Passed } \\
401-2\end{array}$ & Failed \\
\hline H.R. $810^{*}$ & $2 / 9 / 2015$ & NASA Authorization Act of 2015 & Passed & \\
\hline H.R.2262 & $5 / 12 / 2015$ & U.S. Commercial Space Launch Competitiveness Act & $\begin{array}{l}\text { Passed } \\
284-133\end{array}$ & Passed \\
\hline H.R. 6007 & $9 / 13 / 2016$ & $\begin{array}{l}\text { To amend title } 49 \text {, U.S. Code, to include consideration of } \\
\text { certain impacts on commercial space launch and reentry } \\
\text { activities in a navigable airspace analysis, and for other purposes }\end{array}$ & $\begin{array}{c}\text { Passed } \\
425-0\end{array}$ & Passed \\
\hline S.3346* & $9 / 15 / 2016$ & NASA Transition Authorization Act of 2016 & & Passed \\
\hline H.R.321 & $1 / 5 / 2017$ & $\begin{array}{l}\text { Inspiring the Next Space Pioneers, Innovators, Researchers, } \\
\text { and Explorers (INSPIRE) Women Act }\end{array}$ & Passed & Passed \\
\hline S.442 & $2 / 17 / 2017$ & NASA Transition Authorization Act of 2017 & Passed & Passed \\
\hline
\end{tabular}

Notes: Passed without roll results expresses that the bill was passed by Unanimous Consent or by Voice Vote.

*The bill was not presented to President.

We include the drafts to illustrate the changed reality surrounding the NASA Authorization Acts.

Source: U.S. Congress (2018). 


\section{HYPOTHESES}

If we consider a general model of legislative behavior where members of Congress consider constituents desires and personal beliefs in regards to voting for what they see as good policy, we have the following theories about voting on space policy related legislation.

Given the aforementioned problems with understanding public opinion on space issues, we instead assume that legislators serve as trustees of the people on these matters, voting in ways that support the best interest of their constituents rather than based upon their direct desires. Therefore, we believe that members of Congress, lacking a strong public opinion cue for which way to vote, may ignore party cues and instead use economic cues by which they will support legislation that will benefit their constituency's general economic well-being. This leads us to our first testable hypothesis:

\section{DATA \& METHODS}

\subsection{Legislation of Interest}

Using econometric models with space explanatory variables can reveal whether members of the House take into account the importance of space activities and procurements when voting during the floor action. In order to conduct a data driven statistical analysis, rather than continue to rely on antidotal evidence, the most suitable bills and roll-call votes for analysis are those without the unanimous support, as only those pieces of legislation will allow for the revelation of the causes in variation of support. Therefore, we are specifically interested in the following pieces of legislation: the NASA Authorization Act of 1992, the 2000 NASA Authorization Act, the 2004 Commercial Space Launch Amendments Act, the 2010 NASA Authorization Act, and the 2015 Commercial Space Launch Competitiveness Act. Even though the aerospace industry data are not available for the NASA Authorization Act of
H1: Members of Congress will base their support for space legislation upon the degree of importance that the space industry plays in their state.

However, there is another economic cue easily at hand for the members of Congress - NASA procurements allocated to the given state. While extracting information about the absolute and relative importance of the space industry can be time-consuming the information about the NASA procurements is provided by NASA with annual frequency. Hence, the second testable hypothesis is:

H2: Members of Congress will base their support for space legislation upon NASA procurements allocated to the given state.

1992, we still use this vote when testing the hypothesis regarding NASA procurements.

H.R.1988, National Aeronautics and Space Administration Authorization Act, Fiscal Year 1992, was introduced on April 23, 1991. The bill was passed on the floor of the House about a week later with a vote of 361 to 36 . The controversy of this bill is not as clear cut as others in our sample, nor is the vote as contentious. However, the contention is likely economic in nature and thus worthy of consideration. The legislation suggests a large cut back to the funding of Space Station Freedom (a program since evolved into the International Space Station), and Democrats who controlled congress at the time were particularly sensitive to spending issues given the economic recession. Additionally, there was lingering political and economic contention in regards to the Space Exploration Initiative proposed by President George H. W. Bush only two years earlier (Lambright, 2009). 
H.R.1654, the National Aeronautics and Space Administration Authorization Act of 2000, from May 3, 1999. It passed on the floor of the House with a vote of 259 to 168 little bit over two weeks after it was introduced. The controversy of this bill was caused by the House Committee that wanted to terminate the currently known Deep Space Climate Observatory project. Apart from this quite a radical change the Committee introduced variety of small adjustments across the bill. Further amendments passed on the floor influenced the economic impacts of the bill with a changed distribution of the NASA's budget. This bill became an object of politicization which was mitigated in the Senate. After the Senate made some adjustments the bill passed in the House.

H.R.5382, the Commercial Space Launch Amendments Act of 2004, addressed the ambiguity in regulations regarding private spaceflight and was designed to promote the development of the commercial space flight industry. The bill builds on the previous one (H.R.3752) which was highly bipartisan but its legislative journey finished in the Senate after a unanimous passage in the House (402 to 1). The bill was introduced again as H.R.5382 and crafted to be a more balanced as a compromise for the Senate (Capitolwords, 2004). The major controversy of this bill was based on the safety of the passengers and crews of commercial vehicles. Citing the Republican S. L. Boehlert who answered to this controversy that "This bill tries to strike a delicate balance between the need to give a new industry a chance to develop brand-new technology and the desire to provide enough regulation to protect the industry's customers" (Capitolwords, 2004). As a result of previous bills with the same focus this bill wasn't changed significantly during the legislative process. However, the safety and regulation concerns made from a bipartisan bill an issue that divided parties within the House. Interestingly, this bill only marginally affected NASA and its funding, and thus its lack of bipartisan support is unlikely to be explained due to economic impact. This seemingly low controversy bill was introduced on November
18, 2004 and passed the House two days later 269 to 120 .

S.3729, the National Aeronautics and Space Administration Authorization Act of 2010 was introduced after a recently failed H.R.5781, NASA AA of 2010 H.R.5781. S.3729 bill put a larger stress on the development of the new crew transportation system and eliminated the controversy related to the Section 304 regarding the temperature measurements of NASA. The bill still divided the House due to the choice between NASA's manned space program and its partial privatization. The bill eventually passed with a vote of 304 to 118 .

H.R.2262, the U.S. Commercial Space Launch Competitiveness Act of 2015 was mostly a necessary reaction to a development of commercial launch capabilities. As such it was not particularly controversial because it mostly updates liabilities, definitions and some other minor legal aspects. However, there was a rather large controversy raised due to its Title III, a section titled "Space Resource Exploration and Utilization Act of 2015." This shorter part of the Act transfers asteroids and their resources from no-ownership to private-ownership without the global consent, a contradiction to international law. For more on the matter see Nelson (2015) or Tronchetti (2015). Despite this contradiction, the bill passed 284 to 133 .

\subsection{Key Variables of Interest}

In line with the hypotheses the key variables of interest include a set of proxies for the importance of the space industry and the NASA procurements. The importance of the space industry is modeled using two distinct variables. The first is the presence of the NASA center within the member's state. The second is a percentage of employees belonging to the NAICS codes Nr. 336414 to 336419 (space industry as defined in Machay, 2012) on total employment in NAICS code Nr. 336 Transportation equipment manufacturing.

Given the lack of clear public opinion cues on space policy, members of Congress must instead use economic cues in order to serve their constituents' best interests. The importance of 
the space industry serves as an economic proxy and is measured through the existence of a NASA center within the member's state, within the member's district, within the member's neighboring district, and the degree of space industry employment in the state.

NASA centers play a financial and a "prestige" role (Machay and Steinberg, 2015) that might be important for the members of Congress. The support for the space policy legislation does not need to be directly related to financial aspects only. The prestige effect might make some members of Congress being more likely supportive even though there is no direct financial benefit. ${ }^{2}$

The percentage of employees engaged in the space industry will be used as a proxy for a relative importance of space activities within the given state. The variable was created using the NAICS codes data of the U.S. Census Bureau (2016) in a conservative approach described in Machay and Steinberg (2015). This variable measures a direct financial benefit of space related activities manifested in the state's labor market. Members of Congress from states with relatively larger space related labor market should be more likely to support the given bill.

To test the second hypothesis we used the NASA procurements from the contractors based on the geographical distribution which is provided in NASA Annual Procurement Reports (NASA, 2015). The data are real values of NASA spending per capita. Therefore, procurement figures are the NASA allocated dollars being spent in that particular state for goods and services of private contractors recalculated to per capita level.

\subsection{Control Variables}

Previous research in political science has suggested that individual legislator's personal interest towards an issue may play a role in congressional voting (Kau and Rubin, 1993). While much of the political science literature dismisses the role of legislative 'shirking' we still feel it is prudent to control for it (Poole and Romer, 1993; Bender and Lott, 1996). While it would be difficult to know an individual legislator's predisposition towards supporting space policy, previous findings suggest that younger, Republican, well-educated, high-socioeconomic status males are most likely to be the "issue public for space" (Whitman Cobb, 2011). Previous findings of a respondent's political affiliation being associated with space policy may be questionable as men, higher income individuals, and older people are all also more likely to be Republican. In a study controlling for these other factors, party is not seen to be affecting support for space funding increases (Steinberg, 2013). Gender based associations with support for increasing NASA's budget have, however, been re-confirmed. ${ }^{3}$ Additionally, gender has been shown to influence voting on gender based issues more broadly (Swers, 1998). Therefore gender may serve as the best, if not only uncorrelated proxy for individual legislator's personal interest in space policy. ${ }^{4}$

Technical education is an important control both in regards to their knowledge of the topic as well as their underlying interest in space policy. In this study, the variable is defined as postgraduate education in the fields of physics, engineering or aviation technologies, including

\footnotetext{
${ }^{2}$ Some may believe that NASA Centers would be better suited only as a district rather than a state metric. There is good reason to examine it as a state based metric. The first is that the NASA Center may be in one district but those who work for the center may be in a neighboring district. These district lines may also be influenced by redistricting. For example, the Johnson Space Center was part of TX-9 from 1965 to 2005, then part of TX-22 until 2012, and now part of the newly formed TX-36. Therefore, it could be expected that members of congress for any or all of these districts may be influenced by the existence of Johnson Space Center. Moreover, the financial benefits of the center would likely be to the state as a whole. For example, the existence of a NASA center may lead to more jobs in the state, attract skilled workers, bring more industry to the state, and therefore subsequently boost the state's overall economy. Additionally, members with a larger interest may appeal to the state delegation as a whole given the overall potential statewide impacts. See Kingdon (1989) for more on that aspect.

${ }^{3}$ The strong association between gender and support for increased space funding was also found in Steinberg (2013).

${ }^{4} \mathrm{~A}$ member's own personal feelings towards an issue can influence their voting behavior. However, it is often difficult to know if these policy preferences reflect their personal beliefs or if they have previously been influenced or conditioned based upon other factors, such as constituent or party pressures (Kingdon, 1989).
} 
a pilot's license. Additionally, the desire to pursue a technical degree may also demonstrate a personal interest in space policy (Nadeau, 2013). However, given that few members of Congress would fit this category, it is not expected that such a characteristic will play an important role.

The general make up of Congress, being welleducated and of higher economic status than the country as a whole may be part of the reason, at least historically, that so many space policy bills were unanimously or nearly unanimously supported. Given that most members of Congress fit these characteristics, the analysis only controls for technical education, gender, and age. ${ }^{5}$

To control for the possibility that members of Congress would wrongly correlate aircraft manufacturing and the space industry as both benefiting from space related funding, the percentage of aircraft manufacturing (NAICS codes Nr. 336411-3) on the Transportation equipment manufacturing was included in the analysis. Some members of the House might perceive the space industry as tightly related to the aircraft manufacturing industry. Hence, they could support NASA not for its own sake but as a support of this closely related industry. However, they might be oblivious to the details of the space industry. Even though the research shows that these two industries are closely interrelated (see for example Ferguson, 2013). Aircraft manufacturing is therefore also included as in the analysis to examine this potential effect.

It should be noted that the relative importance of the space industry based on NAICS codes does not correlate with the location of NASA centers. This lack of correlation is one of the key reasons to include both variables in the analysis. Each variable, hence, reveals a different dimension of space activities in relation to general public. Even though the space and air activities are seen frequently as similar (Ferguson, 2013), the production sides of these activities are not highly related. The correlation of relative importance of these two industries is practically zero (for example for 2010 data it is 0.02). Two different members of the House from different districts can decide on two different motivations. In one case the motivation can be driven by the support for the jobs in the space industry and the second one by the aircraft manufacturing. Technically educated experts might see the variations in the production processes of these two industries but most of the members of the House do not have technical education. Hence, their support might be based on an apparent similarity of these two. For this reason, it makes sense to control for such misinterpretation of the similarity.

To filter our any relation between general economic state of things at the moment of the vote we included the real GDP per capita from previous year (hence, the data that were available at the moment of the vote) and the rate of unemployment for the given state from a month preceding the vote.

\subsection{Model}

Using logistical regression of the variables of interest and the control variables on the dependent variable of vote choice allows for an examination of our hypotheses. The same general model is employed for each of the rollcall votes of interest:

$$
\begin{aligned}
& \text { Vote Choice }=\beta \text { (age) } \\
& +\beta \text { (gender) } \\
& +\beta \text { (technical education) } \\
& +\beta \text { (party ID) } \\
& +\beta \text { (log of GDP per capita) } \\
& +\beta \text { (unemployment rate) } \\
& +\beta \text { (NASA centers at the state, } \\
& \text { district and neighborhood level) } \\
& +\beta \text { (space industry) } \\
& +\beta \text { (aircraft industry) } \\
& \text { or }+\beta \text { (NASA procurements per capita) }
\end{aligned}
$$

Variables are coded as follows based on the member of Congress at the time of each vote: Vote Choice is coded as one when supporting

\footnotetext{
${ }^{5}$ Even though the average and median age are higher among members of Congress than in general population age still varies significantly (illustrated by the standard deviation shown in Tab. 2).
} 
Tab. 2: Descriptive Statistics of Control Variables

\begin{tabular}{|c|c|c|c|c|c|}
\hline & $\begin{array}{l}\text { NASA AA } \\
\text { of } 1992\end{array}$ & $\begin{array}{c}\text { NASA AA } \\
\text { of } 2000\end{array}$ & $\begin{array}{r}\text { Commercial } \\
\text { Launch } 2004\end{array}$ & $\begin{array}{c}\text { NASA AA } \\
\text { of } 2010\end{array}$ & $\begin{array}{l}\text { Commercial } \\
\text { Launch } 2015\end{array}$ \\
\hline Voted $(N)$ & 399 & 427 & 389 & 422 & 417 \\
\hline Required & $\begin{array}{c}200 \\
\text { (Majority vote) }\end{array}$ & $\begin{array}{c}214 \\
\text { (Majority vote) }\end{array}$ & $\begin{array}{c}260 \\
(2 / 3 \text { vote })\end{array}$ & $\begin{array}{c}282 \\
(2 / 3 \text { vote })\end{array}$ & $\begin{array}{c}209 \\
\text { (Majority vote) }\end{array}$ \\
\hline Democrats & 266 & 211 & 207 & 254 & 188 \\
\hline Males & 406 & 375 & 344 & 352 & 346 \\
\hline Tech Education & 53 & 19 & 18 & 26 & 37 \\
\hline Age Mean & 52.39 & 53.56 & 55.92 & 58.30 & 57.77 \\
\hline Age Min & 30 & 29 & 31 & 29 & 31 \\
\hline Age Max & 81 & 77 & 81 & 87 & 86 \\
\hline Age Standard Deviation & 10.05 & 9.37 & 9.42 & 10.18 & 10.63 \\
\hline NASA Procurements per capita Mean & 37.50 & 33.47 & 31.32 & 37.34 & 34.29 \\
\hline NASA Procurements per capita Min & 0.00 & 0.00 & 0.00 & 0.01 & 0.00 \\
\hline NASA Procurements per capita Max & 270.92 & 180.75 & 168.86 & 245.38 & 317.23 \\
\hline Real GDP per capita Mean & 26,235 & 44,241 & 45,575 & 47,515 & 49,032 \\
\hline Real GDP per capita Min & 17,309 & 17,508 & 30,003 & 31,885 & 31,522 \\
\hline Real GDP per capita Max & 68,487 & 69,570 & 67,998 & 71,114 & 71,056 \\
\hline Unemployment rate Mean & 6.49 & 4.27 & 5.38 & 9.42 & 5.40 \\
\hline Unemployment rate Min & 2.40 & 2.60 & 3.20 & 3.70 & 2.70 \\
\hline Unemployment rate Max & 9.90 & 6.60 & 7.30 & 13.60 & 7.00 \\
\hline Share of space employment Mean & & 4.74 & 4.36 & 4.82 & 5.74 \\
\hline Share of space employment Min & & 0.00 & 0.00 & 0.00 & 0.00 \\
\hline Share of space employment Max & & 37.97 & 47.64 & 52.50 & 53.19 \\
\hline
\end{tabular}

Sources: Civic Impulse (2014a, 2014b, 2014c, 2016), U.S. House of representatives (2016), U.S. Congress (2016, 2018), NASA (2015), BLS (2017), BEA (2017).

a bill and zero when opposing a bill; age is age of the member of the House; gender is coded as one for males and zero otherwise; technical education is coded as one for technical postgraduate education or other forms as mentioned previously and zero otherwise; political party ID is coded one for Democrats and zero for Republicans; real GDP per capita is used in a logarithmic form; unemployment level is used as a percentage; NASA centers is coded one if the member has a NASA center or significant site located within the state they represent, or within the district they have been elected for, or if his or hers district is in close vicinity of such a center; spacecraft represents a percentage of employment in spacecraft manufacturing on transportation equipment manufacturing in the given state and aircraft is a percentage of employment in aircraft manufacturing on transportation equipment manufacturing. Be- tas represent corresponding estimated effects of the variable.

The second model testing the second hypothesis is designed in a similar manner only the variables space industry and aircraft industry are replaced by NASA procurements to private entities. NASA procurements are expressed as dollars per capita for the given state in the year preceding the year of vote.

Correctness of predictions is compared to the correctness of predictions of a "naïve model" where only the constant was used. The performance of the models was measured by the Youden's $J$ statistic calculated as

$$
J=\frac{\mathrm{TP}}{\mathrm{TP}+\mathrm{FN}}+\frac{\mathrm{TN}}{\mathrm{TN}+\mathrm{FP}}-1,
$$

where TP are true positive values, $\mathrm{FN}$ false negatives, TN true negatives, and FP false positives. The closer the Youden's J statistic to one the better the model is. 


\section{RESULTS \& ANALYSIS}

The results of each of the four logit models testing the first hypothesis are presented in Tab. 3. Generally speaking, model design is useful in explaining the behavior of the members of the House except the NASA AA of 2010. This vote was influenced by other aspects since the Youden's $J$ statistic is practically zero. Model as a whole improves the naïve model only slightly. Partly due to the two strong effects estimated within the model. While there is a strong "NASA state level proudness effect" it is counteracted by even stronger "envy effect" of members from NASA center neighboring districts. The effect related with the spacecraft manufacturing is at its mean negligible $(0.8 \%)$. Other votes' results provide support confirming that the NASA proudness effect is strong no matter what is being a subject of the vote. Even though the common sense suggests it should be getting stronger the closer to the center given member is but the proudness effect is the strongest at the state level. The hypothesis, as Authorization Acts which contribute financial benefits appear to be only a bit influenced by the importance of the space industry. Hence, the null hypothesis about no effect cannot be rejected universally. The importance of aerospace industry plays some role but it appears the role is changing in effect and in being in play. It seems members of the House rely on this metric on a vote based basis. Additionally, the results suggest that a members political party is also a strongly predictor in voting for space legislation more generally.

Depending on the bill, at hand, the results suggest that members of Congress act as good trustees for their constituency by supporting bills they believe will provide economic benefits to their constituency. The role of NASA centers in this regard is the clearest. When a piece of legislation is contentious, the results for the 2000 and 2010 Authorization Acts show that in matters of direct funding, members of Congress with a NASA center in their state will indeed support the legislation. The role of the aerospace industry more generally appears to be less clear. This may imply that members of Congress are less aware of the role of industry and instead focus on easier to understand heuristics such as the existence of NASA centers. Alternatively, the legislative connection with NASA centers may be due to non-economic factors that we are unable to take into account in the analysis.

When examining the 2010 Authorization Act, both having a NASA center and having a higher degree of space industry within a member's state were associated with increased likelihood of support. However, the strong "envy effect" of members from neighboring districts counteracted heavily. The fact that there was a divided vote on this piece of legislation perhaps suggests that the national priority of NASA is slipping, or that members who were not likely to see economic benefits for their constituents would rather spend the money elsewhere. Regardless, it implies clear opportunism by legislators.

When examining the effects of industry for the 2000 Authorization Act, the NASA center effect is still present, but so too is a strong positive effect of aircraft manufacturing. This could be an example of wrongly associating the industries or it could actually be more strategic. The Authorization Act of 2000 secured the funds for the development of the second generation reusable launch vehicle. With no doubt, the technological spin-offs of this program would highly benefit the aircraft manufacturing industry.

Given the results in 2000, it is somewhat surprising that the aircraft industry effect was not present in 2010. The decision between the Constellation program and privately provided access to space might have been confusing for legislators with aircraft industry interests as the legislation both increases opportunity for private industry participation while negatively affecting existing contractors. Members of Congress likely lacked knowledge on how to best represent the interest of the aircraft manufacturing industry due to the unclear implications of this radical change. This trend changed five years later when another Commercial Space Launch Act was considered in 
Tab. 3: Aerospace Industry and Legislative Voting

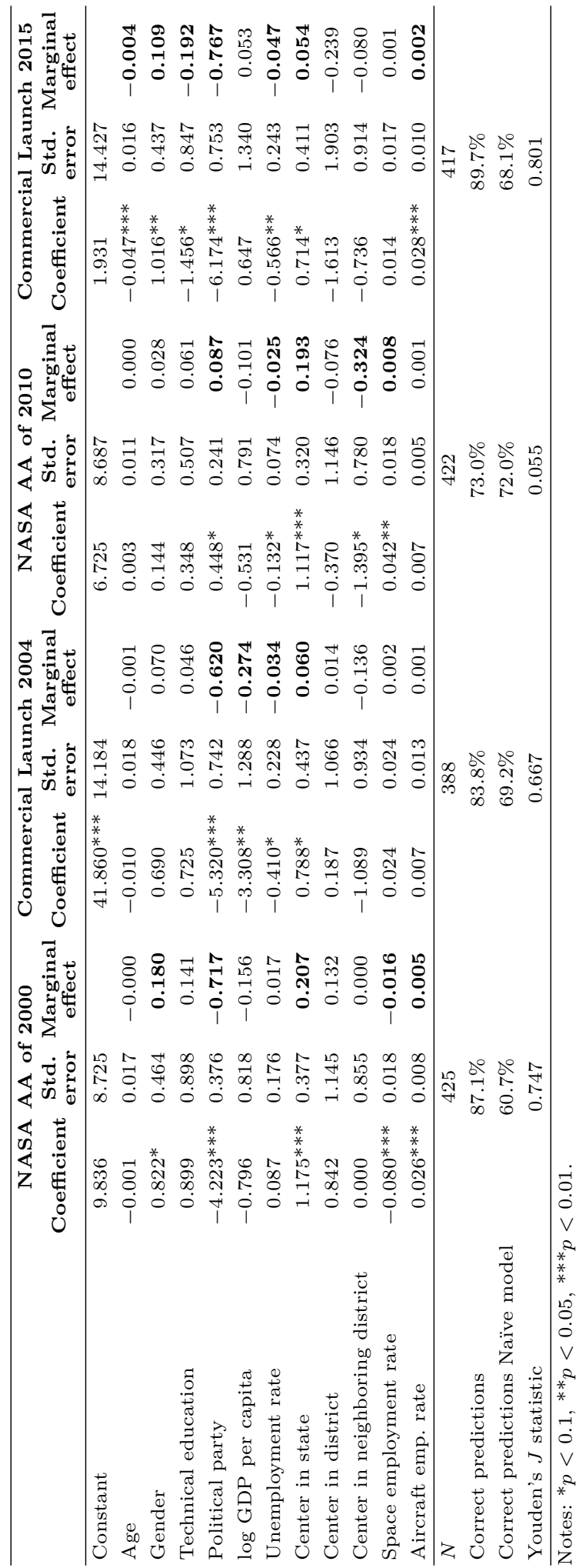

Tab. 4: NASA Procurement and Legislative Voting

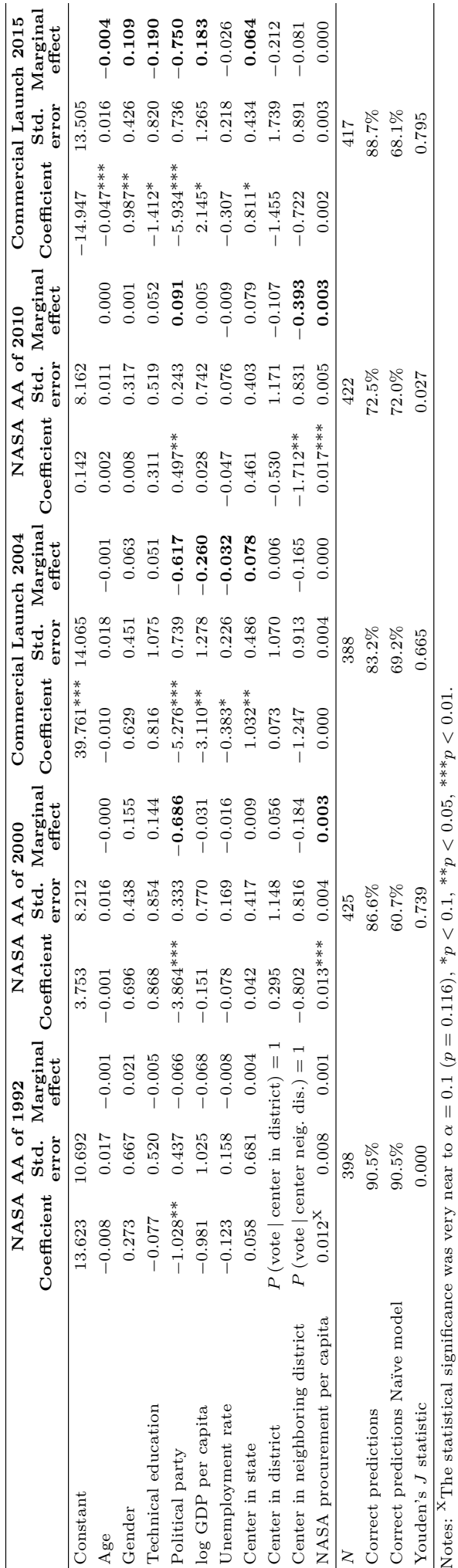


the House as aircraft industry was strongly associated with voting yes on the 2015 vote, while more NASA related economic indicators are not.

Looking at the results more generally, space economic factors were not associated with supporting the 2004 and 2015 legislation that lacked any direct economic impacts. Voting on these bills was subject to party affiliation effects, suggesting that when funding is not at stake a bill can still be susceptible to partisan influences. This outcome may in fact be the most important, suggesting that there is an ideological aspect to be considered in space policy that is often not taken into account.

This suggests that general pieces of legislation are not object of economic opportunism while when the piece of legislation affects or has a potential to affect jobs within the districts the legislators tend to rely on economic metric in their decision making. Resulting effect is then related with expected outcome of the bill.

We started the analysis with testing the first hypothesis that focused on real economic data variables - jobs and NASA presence. However, the second part of the analysis aims at the direct monetary benefits which are an indirect consequence of funds allocated to NASA. ${ }^{6}$ The results testing the second hypothesis are presented in Tab. 4.

Testing the second hypothesis provides one additional vote that can be analyzed - the NASA Authorization Act of 1992. Looking at the Youden's $J$ statistic the quality of the models is slightly worse than in the previous case. An interesting result is obtained for the NASA Authorization Act of 1992. With only 38 members voting against the bill the mean based logit model will predict only yeas. A mean member of the House has a too high probability of voting yea. In this case there is not much of a variability in the data to be explained. Which is shown by probability one in the case of members who are from the districts or neighboring districts with NASA presence.
Not only is the second hypothesis supported but NASA procurements appear to have a stronger explanatory power than the variables related to the relative importance of the aerospace industry. The data show that higher levels of NASA procurement dollars are associated with support for all three authorization acts. For the 2000 and 2010 Authorization Acts the association is significant at the $p<0.01$ level, while for the 1992 Authorization act the association is significant at the $p<0.117$ level. Additionally, in these models NASA centers do not appear to have any explanatory power.

There are two possible explanations. First, while NASA centers and spacecraft manufacturing are not highly correlated, they do reflect in some way the geographical distribution of NASA procurements. On one hand the NASA centers can be a source of procurements in their neighborhoods and on the other the procurements provided in other states took place in the same state where the procurement was awarded - headquarters and production sites of private businesses are located in the same region. Second, it can be easier for the members of Congress to use economic cue in the form of NASA procurements - it is easily at hand instead of extracting the real data on employment from the public labor databases.

Interesting is the alternation of NASA state level proudness effect and NASA procurement. If members vote on money related bill the procurement takes over and the proudness effect dissipates. If a general draft of law is being voted on the procurements are of no consequence for the legislators and they follow the proudness effect. It seems from the results that when money is being in question money matters very much.

Across both hypotheses when legislation deals with NASA's budget, economic cues are at work in decision-making through various forms. However, when a general space policy bill is considered economic cues do not seem to play as much of a role. Even NASA is a subject of economic opportunism of legislators.

\footnotetext{
${ }^{6}$ Notice that the procurements can be earned by the company in the given state but the economic activity (jobs mostly) can take place in another state within the U.S.
} 


\section{CONCLUSION}

The main focus of this paper was to understand the degree of economic opportunism taking place in regards to space policy. This work shows that researchers should consider the potential for economic opportunism within technology policy legislation, especially where the public lacks interest and knowledge such as with space policy. The results presented above clearly demonstrate that these economic effects are indeed present in some cases of space policy legislation. The realities of space policy and space spending do affect legislative decision making.

All three bills concerned with federal spending were accompanied by space related economic opportunism - in one form or another. Meanwhile, bills related to more general policy change that did not have direct budget implications were not as likely to be subject to economic opportunism. While NASA centers may be the simplest heuristic, NASA procurement may be a better one in the case money being the object of interest. NASA centers may serve as more than just an economic heuristic for legislators, and members from given states may be supporting legislation for reasons other than direct economic impact.

However, when considering bill with the most direct monetary effects the explanatory power of the presence of NASA centers vanishes. The results suggest that the individual members of Congress are more likely to consider the direct monetary payoff related with the NASA Authorization Acts via NASA procurements. From this point of view there is strong evidence that the space policy and the funds related with NASA are more about the money than anything else. One could even argue that legislative support for NASA spending is just about the procurements. The more money NASA is spending in a state the more likely representatives from those states will support NASA authorization acts, at least when the bill is controversial due to a policy aspect.

Despite these findings, we must be mindful of generalization based on these five bills as most space related legislation passes in Congress with unanimous support. While the NASA Authorization Acts are accompanied by various degrees of economic opportunism, the evidence for an economic argument is mixed in regards to the space industry when taken alone. The significant negative effect of the spacecraft industry in the 2000 vote is cause for concern regarding economic opportunism, though there are multiple possible explanations.

First, because only a simple majority was needed to pass the bill, this opened the door for more sophisticated voting. Given the strong Republican support towards the bill and the existence of a Republican majority in the house, it was already likely that the bill was going to pass (more on sophisticated voting in Krehbiel and Rivers, 1990; Banks, 1985 or Volden, 1998). Therefore, a legislator could actually vote against the bill with the argument that it does too little for the space industry and space policy. Hence, it is insufficiently beneficial for the voters and the district. The legislator demonstrates to the voters that he is strongly supportive of the cause and capable to articulate his more ambitious ideas. At the same time his opposition does not prevent the bill to pass. In reality nothing would be changed except his voters are now aware of his space activism.

Second, the bill actually harms the interests of the space industry within particular states and thus legislators voted against it in hopes of a revised and more beneficial bill. Legislators from the states where NASA centers are located still voted to support the bill as the negative impact on the industry may not also be a negative impact on the NASA centers themselves. Legislators with NASA Centers in their states may also be under political pressure to support all NASA legislation regardless of the specifics as the public may not understand the nuanced voting and only see their legislator being antiNASA.

Third, the opposition towards the bill could be a factor of politicization of space policy whereby economic concerns failed to outweigh other political concerns. Given the political situation surrounding this particular case, this is 
most likely the cause. Despite that many space policy bills are introduced as bipartisan, they can easily become ones ripe for partisan politics though the addition of provisions that divide the parties. Just in the examples discussed here, these provisions included environmental issues, safety issues - more precisely the extent of governmental regulation, and radical changes in already existing and running programs. Future qualitative research is necessary involving examination of the specific content of space policy legislation to better understand some of the nuanced behavior of legislators.

Despite the potential for economic opportunism, it is rare that the passing of the NASA Authorization Acts is not eventually secured. Most of the work in this arena is done in space responsible committees and subcommittees of Congress. A good example from the recent years is the NASA Authorization Act of 2013. Several attempts were made in Congress to alter NASA's course by the bills H.R.2616 (introduced 7/8/2013), S.1317 (introduced $7 / 17 / 2013$ ) and H.R.2687 (introduced $7 / 15 / 2013)$. None of these pieces of legislation made it from the given sub/committee to the floor. A less-controversial bill, H.R.4412 NASA Authorization Act of 2014 was introduced in April 7th. This bill was a compromise drawing from the above-mentioned bills and with bipartisan support passed the subcommittee (U.S. House of Representatives, 2014). Even though the bill was reshaped to be less controversial, it still failed in the Senate.

Given the strong positive effect of NASA Centers and even stronger effects of NASA procurements, it would seem that it would be in NASA's interests to spread more of their activities across the United States and to highlight the direct monetary benefits for the local economies. This may lead to increase support for NASA across the country rather than support being limited to space related constituencies. This strategy can be especially fruitful in democratic leaning states so that space policy could be more strongly linked to jobs. Meanwhile, NASA can also highlight and stress the link between the space industry and aircraft manufacturing in order to promote support from states with those industries that may not be aware of the impact NASA has on their constituents.

\section{REFERENCES}

Ansolabehere, S., Snyder, J. M. Jr and Steward III, C. 2001. The Effects of Party and Preferences on Congressional Roll-Call Voting. Legislative Studies Quarterly, 26 (4), 533-572. DOI: $10.2307 / 440269$.

BANKS, J. S. 1985. Sophisticated Voting Outcomes and Agenda Control. Social Choice and Welfare, 1 (4), 295-306.

Bender, B. and Lott, J. R. JR. 1996. Legislator Voting and Shirking: A Critical Review of the Literature. Public Choice, 87 (1-2), 67-100.

Bureau of Economic Analysis (BEA). 2017. Regional Data: Annual Gross Domestic Product by State [online]. Available at: https://www.bea.gov/regional/index.htm.

Bureau of Labor Statistics (BLS). 2017. Local Area Unemployment Statistics [online]. Available at: https://www.bls.gov/data/\#unemployment.
Capitolwords. 2004. Commercial Space Launch Amendments Act of 2004 [online]. Washington, DC: Sunlight Foundation. Available at: http://capitolwords.org/date/2004/11/19/ H10045_commercial-space-launch-amendments -act-of-2004.

Civic Impulse. 2014a. H.R.1654 (106th): NASA Authorization Act of 2000 [online]. Washington, DC: GovTrack.us. Available at: https://www. govtrack.us/congress/votes/106-1999/h139.

Civic Impulse. 2014b. H.R.5382 (108th): Commercial Space Launch Amendments Act of 2004 [online]. Washington, DC: GovTrack.us. Available at: https://www.govtrack.us/congress/votes/ 108-2004/h541.

Civic Impulse. 2014c. S.3729 (111th): NASA Authorization Act of 2010 [online]. Washington, DC: GovTrack.us. Available at: https://www . govtrack.us/congress/votes/111-2010/h561. 
Civic Impulse. 2016. H.R.2262: SPACE Act of 2015 [online]. Washington, DC: GovTrack.us. Available at: https://www.govtrack.us/congress/votes/ 114-2015/h262.

Clausen, A. R. 1973. How Congressmen Decide: A Policy Focus. New York, NY: St. Martin's Press. ISBN 0312394454.

Committee on Science, Space and Technology. 2013. Full Committee Markup - H.R.2687, the National Aeronautics and Space Administration Authorization Act of 2013 [online]. Available at: http://science.house.gov/markup/ full-committee-markup-hr-2687-national -aeronautics-and-space-administration -authorization-act.

Davis, O., Dempster, M. A. H. and Wildavsky, A. 1966. A Theory of the Budgetary Process. American Political Science Review, 60 (3), 529-547.

Ferguson, R. G. 2013. NASA's First A: Aeronautics from 1958 to 2008. Washington, DC: NASA. NASA SP-2013-4412.

Fiorina, M. P. 1974. Representatives, Roll Calls, and Constituencies. Lexington, MA: Lexington Books. ISBN 0669902179.

Hoff, J. 1997. The Presidency, Congress, and the Deceleration of the U.S. Space Program in the 1970s. In LAunius, R. D. and MCCurdy, H. E. (eds.). Spaceflight and the Myth of Presidential Leadership. Chicago, IL: University of Illinois Press, pp. 92-132.

KAU, J. B. and Rubin, P. H. 1979. Self-Interest, Ideology and Logrolling in Congressional Voting. Journal of Law and Economics, 22 (2), 365-384. DOI: $10.1086 / 466947$.

KAU, J. B. and Rubin, P. H. 1993. Ideology, Voting, and Shirking. Public Choice, 76 (1/2), 151-172.

KING, L. 2013. Showdown over NASA Funding Likely [online]. USA Today. Available at: http: //www . usatoday.com/story/news/politics/2013/ 07/31/nasa-funding-battle-congress/2602319.

Kingdon, J. W. 1977. Models of Legislative Voting. The Journal of Politics, 39 (3), 563-595. DOI: $10.2307 / 2129644$.

Kingdon, J. W. 1989. Congressman's Voting Decisions. University of Michigan Press, 3rd ed. ISBN 0472064010.

Krehbiel, K. and Rivers, D. 1990. Sophisticated Voting in Congress: A Reconsideration. The Journal of Politics, 52 (2), 548-578. DOI: $10.2307 / 2131906$.
LAMBRIGHT, W. H. 2009. Leading in Space: 50 Years of NASA Administrators. In Dick, S. J. (ed.). NASA's First 50 Years: Historical Perspectives. Washington, DC: U.S. Government Printing Office, pp. 49-78.

Launius, R. D. 2003. Public Opinion Polls and Perceptions of US Human spaceflight. Space Policy, 19 (3), 163-175. DOI: $10.1016 /$ S0265-9646(03)00039-0.

Launius, R. D. and McCurdy, H. E. 1997. Beyond NASA Exceptionalism. In LAunius, R. D. and McCurdy, H. E. (eds.). Spaceflight and the Myth of Presidential Leadership. Chicago, IL: University of Illinois Press, pp. 221-250.

LeOne, D. 2013. Senate, House NASA Bills Far Apart on Funding, Close on Some Priorities [online]. SpaceNews. Available at: http:

//www.spacenews.com/article/civil-space/ 36339senate-house-nasa-bills-far-apart-on -funding-close-on-some-priorities.

Machay, M. 2012. A Brief Analysis of US Space Employment. Space Policy, 28 (2), 125-129. DOI: $10.1016 /$ j.spacepol.2012.02.004.

Machay, M. and Steinberg, A. 2015. The Influence of Industry on Legislative Behavior toward NASA. Astropolitics: The International Journal of Space Politics \& Policy, 13 (2-3), 205-222. DOI: $10.1080 / 14777622.2015 .1083812$.

MacRae, D. 1958. Dimensions of Congressional Voting. Berkley, CA: University of California Press.

Mayhew, D. R. 1974. Congress: The Electoral Connection. New Haven, CT: Yale University Press. ISBN 0300130015.

Nadeau, F. 2013. Explaining Public Support for Space Exploration Funding in America: A Multivariate Analysis. Acta Astronautica, 86, 158-166. DOI: 10.1016/j.actaastro.2013.01.004.

NASA. 2015. Annual Procurement Reports [online]. Available at: https://prod.nais.nasa.gov/pub/ pub_library/annual_proc_reports_index.html.

Nelson, T. G. 2015. Mining Outer Space: Who Owns the Asteroids? [online]. New York Law Journal, July 29. Available at: https://www.skadden.com/sites/default/files/ publications/070071539Skadden.pdf.

Peltzman, S. 1984. Constituent Interest and Congressional Voting. Journal of Law and Economics, 27 (1), 181-210.

Pomeroy, C. 2019. The Quantitative Analysis of Space Policy: A Review of Current Methods and Future Directions. Space Policy, 48, 14-29. DOI: $10.1016 /$ j.spacepol.2018.08.001. 
Poole, K. T. and Romer, T. 1993. Ideology, "Shirking", and Representation. Public Choice, 77 (1), 185-196. DOI: 10.1007/BF01049232.

Snyder, J. M. JR. and Groseclose, T. 2000. Estimating Party Influence in Congressional Roll-Call Voting. American Journal of Political Science, 44 (2), 193-211. DOI: 10.2307/2669305.

SpaceRef. 2013. Committee Republicans Set NASA up to Fail with Flawed Bill - Positive Democratic Alternative Defeated [online]. Available at: http: //spaceref . com/news/viewpr.html?pid=41219.

Steinberg, A. 2011. Space Policy Responsiveness: The Relationship between Public Opinion and NASA Funding. Space Policy, 27 (4), 240-246. DOI: $10.1016 /$ j.spacepol.2011.07.003.

Steinberg, A. 2013. Influencing Public Opinion of Space Policy: Programmatic Effects versus Education Effects. Astropolitics: The International Journal of Space Politics \& Policy, 11 (3), 187-202. DOI: $10.1080 / 14777622.2013 .841534$.

Stigler, G. J. 1971. The Theory of Economic Regulation. The Bell Journal of Economics and Management Science, 2 (1), 3-21. DOI: $10.2307 / 3003160$.

Stimson, J. 1975. Five Propositions About Congressional Decision-Making: An Examination of Behavioral Inferences from Computer Simulation. Political Methodology, 2 (4), 415-436.

Swers, M. L. 1998. Are Woman More Likely to Vote for Women's Issue Bills than Their Male Colleagues? Legislative Studies Quarterly, 23 (3), 435-448.

Tronchetti, F. 2015. The Space Resource Exploration and Utilization Act: A Move forward or a Step Back? Space Policy, 34, 6-10. DOI: 10.1016/j.spacepol.2015.08.001.
U.S. Census Bureau. 2016. 2011 County Business Patterns (NAICS) [online]. Washington, DC. Available at: http://censtats.census.gov/ cgi-bin/cbpnaic/cbpdetl.pl.

U.S. Congress. 2016. Biographical Directory [online]. Washington, DC: Congress. Available at: http://bioguide.congress.gov/biosearch/ biosearch.asp.

U.S. Congress. 2018. Legislation [online]. Washington, DC: The Library of Congress. Available at: https://www . congress.gov/advanced-search/ legislation.

U.S. House of Representatives. 2014. Space Subcommittee Approves Bipartisan NASA Authorization Act [online]. Washington, DC: Congress. Available at: http://science.house.gov/press-release/ space-subcommittee-approves-bipartisan -nasa-authorization-act.

U.S. House of Representatives. 2016. History, Art and Archives: People Search [online]. Washington, DC: Congress. Available at: http://history.house.gov/People/Search/.

Volden, C. 1998. Sophisticated Voting in Supermajoritarian Settings. The Journal of Politics, 60 (1), 149-173. DOI: 10.2307/2648005.

Whitman CobB, W. N. 2011. Who's Supporting Space Activities? An 'Issue Public' for US Space Policy. Space Policy, 27 (4), 234-239. DOI: $10.1016 /$ j.spacepol.2011.09.007.

Wildavsky, A. B. 1964. The Politics of the Budgetary Process. Boston, MA: Little, Brown. 216 pp.

\section{AUTHOR'S ADDRESS}

Martin Machay, Department of Economics, Faculty of Business and Economics, Mendel University in Brno, Zemědělská 1, 61300 Brno, Czech Republic, e-mail: machay@mendelu.cz

Alan Steinberg, West Houston Association, Memorial City Plaza Two, 820 Gessner Suite 1310, Houston, TX 77024 